\title{
Ethno-Pharmacognosy and Diversity Encourage Conservation of Wild Ziziphus species Collected from KP, Pakistan
}

\author{
Nisar Uddinn ${ }^{1}$, Noor Muhammad ${ }^{1}$, Naziat Begum ${ }^{1}$, Mohammad Nisar $^{2}$ and Niaz Ali ${ }^{1 *}$ \\ ${ }^{1}$ Department of Botany, Hazara University Mansehra, Pakistan \\ ${ }^{2}$ Department of Botany, University of Malakand, Pakistan
}

Submission: April 05, 2019; Published: April 22, 2019

"Corresponding author: Niaz Ali, Department of Botany, Hazara University Mansehra, KPK, Pakistan

Abstract

The current research works to show that the medicinal practices of two different wild Ziziphus species (Ziziphus oxyphylla Edgew and Ziziphus mauritina Lamk), to assess the consensus factor between local communities of different areas of KP, to measure the potential for novel drugs of herbal origin. There was immeasurable promise among the informers concerning medicinal uses of plants with Informants Consensus Factor (ICF) value ranges from 0.992 to 0.124 with an average value as 0.440 . The study naked that most of the informants agreed in the application of Z. oxyphylla to use and against Jaundice (ICF 0.992) that unveiled the highest fidelity level (100\%) respectively.

The present work has tried to genetic relationships among of Ziziphus species growing in Swat Valley, KP, Pakistan. The intra and inter genetic diversity among the 50 genotypes of Ziziphus species viz., 25 genotypes of Z. oxyphylla, 25 of $Z$. mauritina, were tested using morphometric and biochemical profiling. Twenty-four morphological characters were counted for the assessment of intra and inter genetic diversity through traits similarity index and cluster analysis. Total seed protein profiling was carried out on $12 \%$ slab gel electrophoresis; 12 reproducible bands were noticed in Z. muritiana and 8 Z. oxyphylla. Intra locus contribution toward the genetic disagreement was $41.666 \%$ in Z. oxyphylla and $25 \%$ in $Z$. muritiana. In the same way, inter species locus contribution toward genetic diversity was $66.666 \%$. Fascinatingly, locus L-1, 6, 7, 8 was monomorphic in the collected germplasms and may be presented as generic specific locus for Ziziphus species.

Keywords: Wild Ziziphus species; Ethno botanical uses; Quantitative traits; SDS PAGE; Genetic diversity; Multivariate analysis

Abbreviations: ICF: Informants Consensus Factor; PRA: Participatory Rural Appraisal; FL: Fidelity Level; BPB: Bromo-Phenol Blue; LCTGD: Locus Contribution Toward Genetic Disagreement

\section{Introduction}

The genus Ziziphus consists of almost 100 species has been used in folk and alternative systems of treatment in order to combat different diseases such as; fever, diabetes, skin infections, antipyretic, antinociceptive, antioxidant, antilisterial and larvicidal [14]. Due to peculiar geographical region, Pakistan exhibits a great diversity of flora as represented by 7 genera along with 13 species for Ziziphus [5].

Ziziphus oxyphylla Edgew (synonym; Ziziphus acuminata Royle) also written as "Zizyphus oxyphylla Edgew" belongs to the genus Ziziphus and family Rhamnaceae (known as buckthorn family). The plant $Z$. oxyphylla, popular with common names i.e. Mamyanu, Elanai, Tukbari, Phitni, Amlai and Sezen is a small glabrous tree with short, recurved and unequal spine along with edible fruit (oval in shape), belongs to the genus Ziziphus. Based on folklore use, the plant is in-use for traditional treatment of diseases i.e. jaundices, diabetes, hypertension as well as in gas trou bles [6-9], since long, Z. oxyphylla distributed in different areas of Pakistan, but mostly in warm temperate and subtropical regions throughout the world, especially in Pakistan and India. In Pakistan it may be found in different regions, particularly the rainy and mountain areas as well as the Himalayan series of mountains. The plants is distributed as; Swat Valley, Northern Pakistan, Chagharzai valley, District Buner, KP, Pakistan [9], Buner, Hazara, Swat, Garhi Habibullah, Dir Kohistan valleys, Pakistan [6,10], Kot Malakand agency, Islamabad, subtrop-ical hills of Darazinda, Takht-eSuleman range Dera Ismail Khan, Pakistan, Palas Valley, Pakistan, Kotli, Azad Jammu Kashmir, Pakistan [11-13].

Ziziphus mauritina Lamk, is most important an well-known species of Ziziphus belonged to buckthorn family Rahmnaceaes. $Z$. mauritiana genotypes are very important medicine, ethno medicine and traditionally for the control of different diseases cough, sore throat, anti-oxidant, high fevers, jaundice, diabetes and hypertension etc, [14-16s]. well distributed in different region of 
tropical and sub-tropical areas of the world and mostly found in all continent of the world and native of Afghanistan, Australia, North Africa, North India, Malaysia, and southern China and Pakistan Z. mauritiana is a dominates species/variety of wild vegetation in different arid and as well as desert while in great examples of drought and hard species of Ziziphus $[17,18]$. In Pakistan, it is widely distributed in three provinces i.e. KPK, (Banuu, Karak and Kohat) while district swat, Buner and Dir is found in only wild from, Punjab (Attock, Chakwal and Mianwali districts) and Sindh province (Karachi, Hyderabad and Nawabshah districts). In Pakistan, jujube is cultivated on an area about 5.425 ha with an annual production of 28.000 tones [19].

There is lack of information regarding jujube cultivars in Pakistan. Indigenous cultivars are missing and there is little research work available on their botanical classification [18]. Fluctuation in yield and quality of jujube fruit is greatly affected by the soil properties, climatic factors and cultivar selection [20]. Fruit quality attributes largely depend upon cultivar to be selected. Previously, variations in fruit weight, juice content [21] and seed weight has been recorded in jujube cultivars [22].

Morpho-biochemical methods are used to screened best genotypes in large collected germplasm of different crop species [2330]. Among these methods the SDS-PAGE method is effectively used to determinate the taxonomic and evolutionary difficulties of certain plant species [28]. The seed storage protein studies help in documentation and description of variability in crop varieties, cultivars and their wild species but also rich genetic variability and phylogeny association of the accessions. It is considered that variability in protein bands intricate the association among the assortment from various geographical regions [31]. SDS PAGE as a powerful tool that has been used in the solution of problems in the field of taxonomy and explains the origin and evolution of cultivated plants, including the fenugreek [32].

It provides maximum variability among different crop species and the level of polymorphism depends upon the plant species [33]. Haliem and Huqail [34] found 168 different polypeptides bands among diverse Fenugreek genotypes of Saudi Arab and Yemen through SDS-PAGE method. They recorded 26 different polymorphic bands characterized Brassica rapa sub-species brown sarson through this method and recorded $83.33 \%$ polymorphic protein bands. They also noted four different cluster groups for the twenty studied genotypes. Jan et al. [28], evaluated three different ecotypes of B. rapa through SDS-PAGE method and high level of variability were noted in protein bands size. Protein electrophoresis is considered a reliable, practical and reproducible method because seed storage proteins are the third hand copy of genomic DNA and largely independent of environmental fluctuations $[34,35]$.

The main objectives of the current research studies on Ziziphus species (1) ethno medicinal uses of Ziziphus species in local peoples (2) to explore different aspects the genetic relationship of wild Ziziphus species (Z. oxyphylla and Z. mauritiana) genotypes based on different morphometric collected from different regions of district Swat KP, Pakistan (2) to study genetic diversity based on store seed protein (SDS-PAGE) of wild Ziziphus species of their genotypes (3) by the using of multivariate analysis, phylogenetic, PCA, for the checking of their relationship of wild Ziziphus species collected from different regions of distract Swat KP, Pakistan.

\section{Material and Methods}

\section{Samples collection and Ethno-pharmacognosy}

Exploratory trips were arranged to different areas of KP, Pakistan years, 2017-2018 and total two Ziziphus species (50 genotypes) were identified and investigated for morphological characterization and SDS PAGE protein profiling. The plants (Ziziphus species) Z. oxyphyla and Z. mauritina specimen were store in the herbarium Department of Botany, Hazara University, Mansehra, KP, Pakistan; the specimens were recognized referring different Floras, viz., Hooker (1872-1897). Ethno medicinal data has been collected through Participatory Rural Appraisal (PRA), which is based on communication with indigenous people and direct communication in the field Martin [36]. The data have been noted through semi-structured interviews with people involved in the plants, organization [37]. A total of 130 residents have been interviewed during the field survey, information on uses of plants to cure various diseases of human being, parts used, of medicine have been collected. Based on the information obtained from the informants in the study area, all the reported diseases have been classified into 12 groups.

The different level of the similarity among information delivered by various informants was calculated by the Informants' Consensus Factor, ICF Trotter and Logan [38] by applying the following formula:

$$
I C F=N u r-N t /(N u r-1)
$$

Where, Nur = number of use reports from informants for a specific plant-use category; $\mathrm{Nt}=$ number of taxa or species that are used for that plant use category for all informants.

ICF Values range between 0 and 1 , where ' 1 ' indicates the highest level of informant agreement. The fidelity level (FL), the percentage of informants claiming the use of a certain plant species for the same major purpose, was calculated for the most frequently reported diseases or ailments as:

$$
F L(\%)=(N p / N) \times 100
$$

Where, $\mathrm{Np}$ = number of informants that claim a use of a plant species to treat a particular disease; $\mathrm{N}=$ number of informants that use the plants as a medicine to treat any given disease [37].

\section{Morphological analysis}

In the current work qualitative and quantitative characterizations were carried out of the collected samples, Qualitative traits were recorded on the general visualization (phenotypic observations). Ten qualitative traits i.e. Tree vigor, Leaf type, Leaf shape, Leaf colure, Tomentose, stem color, Spines, fruit color, leaf 
margin, fruit shape and quantitative characters which were measured with the help of vernier caliper for the measurement of plant height(feet), Branching, Leaf length( $\mathrm{mm})$, Leaf width(mm), Leaf thickness(mm), Petiole length( $\mathrm{mm})$, Inter node length $(\mathrm{cm})$, Stem diameter(inches), fruit weight, fruit diameter ( $\mathrm{mm}$ ) and fruit length (mm).

\section{Protein extraction and their preparation}

Total seed protein (SDS-PAGE), a single mature and uncontaminated seed of Z. oxyphylla and Z. muritiana was selected for the analyses of total protein form each genotype collected from different regions of Swat KP, Pakistan. The seed was ground through the pestle and mortar and for the extraction of total protein and were add $400 \mu \mathrm{l}$ protein extraction buffer composition as $(0.5 \mathrm{M}$ TrisHCL pH 8.0, 0.2\% SDS, 5M Urea, 1\% B-mercaptoethanol) to $0.1 \mathrm{~g}$ of seed powder into $1.5 \mathrm{~mL}$ eppendr of tube and then vertex for three (3), mints thoroughly to homogenize the powder and solution.

Bromo-Phenol Blue (BPB) solution was added to the protein extraction buffer as tracking dye to monitor the movement of protein in the gel, then samples were centrifuge for 40 mints at $14,000 \mathrm{rpm}$ at $10{ }^{\circ} \mathrm{C}$ and follow the standard electrophoretic method $[4,39]$. After centrifugation samples the curd protein were recovered as a clear supernatant on the top of the tube. Then were transferred into a new tube and were store at $120{ }^{\circ} \mathrm{C}$ until electrophoresis. After that for the checking of make $12 \%$ polyacrylamide gel the separation gel were making form the mixing of $(3.0 \mathrm{M}$ Tris$\mathrm{HCl} \mathrm{pH9.0,} \mathrm{0.4 \%} \mathrm{SDS)} \mathrm{and} \mathrm{4.5 \%} \mathrm{stacking} \mathrm{gel} \mathrm{(0.4M} \mathrm{Tris-} \mathrm{HCl} \mathrm{pH8.0,}$ $0.4 \%$ SDS), Electrode buffer (0.025 M Tris, 129 M Glycine, $0.125 \%$ SDS) was add into the top of the gel plate and select total volume as $8 \mu \mathrm{l}$ of the protein extraction mixture were loaded into each well of the gel with the help of micropipette and add molecular markers and finally run $100 \mathrm{~V}$ until the blue color were passed through the bottom of the gel plates, the gel were stained by the staining solution containing $0.2 \%$ BPB dissolved in $10 \%$ glacial acetic acid,
$40 \%$ methanol and water in the ratio of 10:40:50. Gels were destained in a solution consisting 5\% acetic acid and $20 \%$ methanol for 15 minutes [40].

\section{Data analysis}

The current data was recorded from the design gel (destined) on the basis of absences and presences of total seed protein gel bands, 1 is denoted for the presence and 0 , for the absence of the loci were arranged in Microsoft excel 2010, and this 0, 1 data were analyzed for cluster analysis and PCA (Principles Component Analysis) was performed by PCord 5.0, SSPS and Statistics.

\section{Results}

\section{Ethno-pharmacognosy}

The current research work on two wild Ziziphus species $Z$. oxyphylla and Z. mauritina collected from different regions of $\mathrm{KP}$, Pakistan, we have been in listed for control of diseases categories as12 and for each Ziziphus species, scientific name, family, local name, illnesses to be treated, and parts used for the different diseases were noted in (Table 1). Consumption of plant parts as medicine among the informants shows disparities. Fruits are mostly used part for majority, followed by roots, leaves and bark, this was the first time of the study area threat to the species is marginal as seeds are the leading plant part used for medicinal purposes. It was supposed that the collection of part of plant as medicinal part from the wild were not manageable. According to residents, this type of activity is done by the collectors related to illegal activity of medicinal plants. Ziziphus species mostly Z. oxyphylla is vulnerable to this type of activity in the study region. ICF values were established to know the settlement among the informants of Swat valley for usage of plants to cure certain illness groups. The ICF values ranges from 0.992 to 0.124 with an average value of 0.440 . Jaundice has the highest ICF value 0.992 with 130 use-reports for 2 plant species.

Table 1: Showed chemical constituents, botanical name, Common name, parts used and their habit of wild Ziziphus species collected from KP, Pakistan.

\begin{tabular}{|c|c|c|c|c|c|c|}
\hline S.NO & Scientific Name & Family & Common Name & Chemical Constituent/Compounds & Habit & Use Parts \\
\hline 1 & $\begin{array}{l}\text { Ziziphus oxyphylla } \\
\text { Edgew }\end{array}$ & Rhamnaceae & Enalai & $\begin{array}{l}\text { Alkaloid, O desmethylnummula- } \\
\text { rine-R N-oxide, Oxyphylline-E, Ra- } \\
\text { mosine-A, Hemsine-A N-oxide, Kae- } \\
\text { mpferol-3-O-galactoside (Trifolin), } \\
\text { Flavonoids Kaempferol-3-0-rhamnosyl } \\
\text { (1-6)-(4"-trans-p-coumaroyl)-, galacto- } \\
\text { side,,Quercetin-3-0-glucoside (Isoquer- } \\
\text { cetrin), Oxyphylline-A 14-membered } \\
\text { cyclopeptide, Kushecarpin-A }\end{array}$ & Shrub tree & $\begin{array}{l}\text { Leaves, Root, } \\
\text { Fruit, Pericarp }\end{array}$ \\
\hline 2 & $\begin{array}{c}\text { Ziziphus mauritina } \\
\text { Lamk, }\end{array}$ & Rhamnaceae & Wild Ber & $\begin{array}{c}\text { Betulinic aldehyde, betulinic acid, ceanoth- } \\
\text { ic acid, frangufoline, spinosin, daucosterol, } \\
\text { sucrose, docosanoic acid, stearic acid and } \\
\text { Palmitic acid }\end{array}$ & Tree & $\begin{array}{c}\text { Fruit, Leaves, } \\
\text { Tuber }\end{array}$ \\
\hline
\end{tabular}

The specie liable for this high consensus was Z. oxyphylla with 130 of the defined events, linked by Blood purification values for ICF $0.8140,107$ use reports and 2 species respectively, for the use of Digestive infection ICF values 0.682, 90 and for 2 species etc (Table 2). Medicinal plants thought to be effective in treating specific illness have high ICF values. The high ICF value for Urinary infection possibly unveiled that this ailment is common in the study area High ICF values also designate that the specie predictably used to treat these illnesses are worth searching for bioactive compounds. The least agreement $(\mathrm{ICF}=0.124)$ between the informers was detected for plants used to cure Lever protection. The low ICF value as noted in our study could be due to a lack of com- 
munication among people in various areas. To discover conventionally significant medicinal species in the society, Fidelity Level (FL) of plants has been predicted based on use reports which have been cited by 50 or more informants for being used against a given disorder and the examination demonstrated that the highest FL value found in $Z$. oxyphylla followed by $Z$. mauritina respectively. The least FL value was found in the case of Z. oxyphylla. FIC and

Table 2: Categories of diseases and *ICF (Informants consensus factor) for each genotype for two wild Ziziphus species and different diseases groups based on highest fidelity level ( ${ }^{\star} \mathrm{FL} \%$ ) in each category TF\% (Total informants=130).

\begin{tabular}{|c|c|c|c|c|}
\hline Counts & Diseases category & Reports & Taxa Used & *ICF \\
\hline 1 & Jaundice & 130 & 2 & 0.992 \\
\hline 2 & Blood Purification & 107 & 2 & 0.814 \\
\hline 3 & Digestive Infection & 90 & 2 & 0.682 \\
\hline 4 & Anti-diabetic & 90 & 2 & 0.682 \\
\hline 5 & Hypertension & 77 & 2 & 0.372 \\
\hline 6 & Gas Troubles & 50 & 2 & 0.295 \\
\hline 7 & urinary Diseases & 40 & 2 & 0.217 \\
\hline 8 & Fungal Disease & 30 & 2 & 0.202 \\
\hline 9 & Obesity & 28 & 2 & 0.171 \\
\hline 10 & Constipation & 24 & 1 & 0.14 \\
\hline 11 & Wounds of Healing & 17 & & 0.124 \\
\hline 12 & Lever Protection & Fidelity Level (FL \%) & Reported & Fidelity Level (FL \%) \\
\hline & Botanical name & Diseases category & 130 & 100 \\
\hline
\end{tabular}

\section{Morphological characterization}

In the current work qualitative and quantitative characterizations were carried out of the collected samples, Qualitative traits were noted on the general visualization (phenotypic observations). qualitative traits i.e. Leaf pubescent, Leaf shape, Leaf col-
FL studies presented that the most commonly used species in the study area are Z. oxyphylla (ICF $=0.992$ ) with 130 use-reports and FL value $(100 \%)$. When choosing the most ideal plant species for each ailment category, we took the high-fidelity Level (\%) in each category of ailment due their high biological compounds which were used for the control of various numbers of diseases (Table 2). or, fruit color, Seed shape and quantitative characters which were measured with the help of vernier caliper for the measurement of plant height (feet), Branching, Leaf length ( $\mathrm{mm}$ ), Leaf width ( $\mathrm{mm})$, Leaf thickness ( $\mathrm{mm})$, Petiole length $(\mathrm{mm})$, Inter node length $(\mathrm{cm})$, Stem diameter (inches), fruit weight, fruit diameter $(\mathrm{mm})$ and fruit length $(\mathrm{mm})$.

Table 3: Intra and interspecific genetic diversity in 17 morphological characters studied in Z. muritiana.

\begin{tabular}{|c|c|c|c|c|c|c|c|c|c|c|c|}
\hline & PH & BR & LL & LW & LT & PL & InL & StD & FtW & FtD & FtL \\
\hline $\mathrm{PH}$ & 1 & & & & & & & & & & \\
\hline $\mathrm{BR}$ & -0.26 & 1 & & & & & & & & & \\
\hline LL & 0.12 & 0.23 & 1 & & & & & & & & \\
\hline LW & 0.14 & 0.12 & $0.860^{* *}$ & 1 & & & & & & & \\
\hline LT & $-.464^{*}$ & 0.02 & 0.16 & 0.26 & 1 & & & & & & \\
\hline PL & 0.28 & -0.17 & -0.39 & $-.496^{*}$ & $-.586^{* *}$ & 1 & & & & & \\
\hline InL & $.574^{* *}$ & -0.11 & $-.418^{*}$ & $-.511^{* *}$ & $-.571^{* *}$ & $.512^{* *}$ & 1 & & & & \\
\hline StD & $.681^{* *}$ & -0.34 & -0.27 & -0.24 & -0.24 & $.533^{* *}$ & $.526^{* *}$ & 1 & & & \\
\hline FtW & -0.29 & 0.14 & -0.17 & -0.32 & 0.01 & 0.15 & 0.05 & -0.02 & 1 & & \\
\hline $\mathrm{FtD}$ & 0.01 & -0.14 & 0.2 & 0.1 & -0.13 & 0 & -0.08 & 0.05 & $.492 *$ & 1 & \\
\hline FtL & 0.11 & 0.04 & 0.25 & 0.11 & 0.04 & -0.2 & 0.15 & 0.15 & $.515^{* *}$ & $.774^{* *}$ & 1 \\
\hline \multicolumn{12}{|c|}{ *. Correlation is significant at the 0.05 level (2-tailed). } \\
\hline \multicolumn{12}{|c|}{ **. Correlation is significant at the 0.01 level (2-tailed). } \\
\hline
\end{tabular}

By using the Pearson correlation coefficient, the result for the association coefficient among the various traits for the two species of Ziziphus (Z. oxyphylla and Z. muritiana) was performed (Table 3 and 4). In correlation study the petiole length in the Z. oxyphylla, is 


\section{Agricultural Research \& Technology: Open Access Journal}

negatively correlated with leaf length in the while positively correlated with leaf length in $Z$. muritiana. Leaf width is negatively correlated with the leaf length in Z. oxyphylla while positively cor- related in the Z. muritiana. The flower length in Z. muritiana and Z. oxyphylla is negatively correlated with the leaf length and leaf width and so on.

Table 4: Intra and interspecific genetic diversity in 17 morphological characters studied in Z. oxyphylla.

\begin{tabular}{|c|c|c|c|c|c|c|c|c|c|c|c|}
\hline & PH & BR & LL & LW & LT & PL & InL & StD & FtW & FtD & FtL \\
\hline $\mathrm{PH}$ & 1 & & & & & & & & & & \\
\hline $\mathrm{BR}$ & 0.05 & 1 & & & & & & & & & \\
\hline LL & -0.01 & $.446^{*}$ & 1 & & & & & & & & \\
\hline LW & $.527^{* *}$ & 0.33 & $.396^{*}$ & 1 & & & & & & & \\
\hline LT & 0.05 & 0.14 & 0.03 & 0.21 & 1 & & & & & & \\
\hline PL & $.444^{*}$ & -0.1 & 0.25 & $.489 *$ & $.401^{*}$ & 1 & & & & & \\
\hline InL & 0.35 & -0.15 & -0.23 & 0.04 & -0.1 & -0.06 & 1 & & & & \\
\hline StD & $.761^{* *}$ & -0.17 & -0.09 & $.499 *$ & 0.13 & $.487^{*}$ & $.439 *$ & 1 & & & \\
\hline FtW & 0.09 & -0.24 & $-.658^{* *}$ & -0.17 & 0.29 & -0.01 & -0.06 & 0.01 & 1 & & \\
\hline FtD & -0.07 & $.534^{* *}$ & -0.01 & 0.17 & 0.21 & -0.11 & 0.09 & -0.23 & 0.28 & 1 & \\
\hline FtL & -0.11 & $.476^{*}$ & -0.08 & 0.08 & 0.12 & -0.21 & 0.06 & -0.31 & 0.36 & $.963^{* *}$ & 1 \\
\hline \multicolumn{12}{|c|}{ **. Correlation is significant at the 0.01 level (2-tailed). } \\
\hline & & & & rrelatio & gnific & the 0.05 & l (2-tail & & & & \\
\hline
\end{tabular}

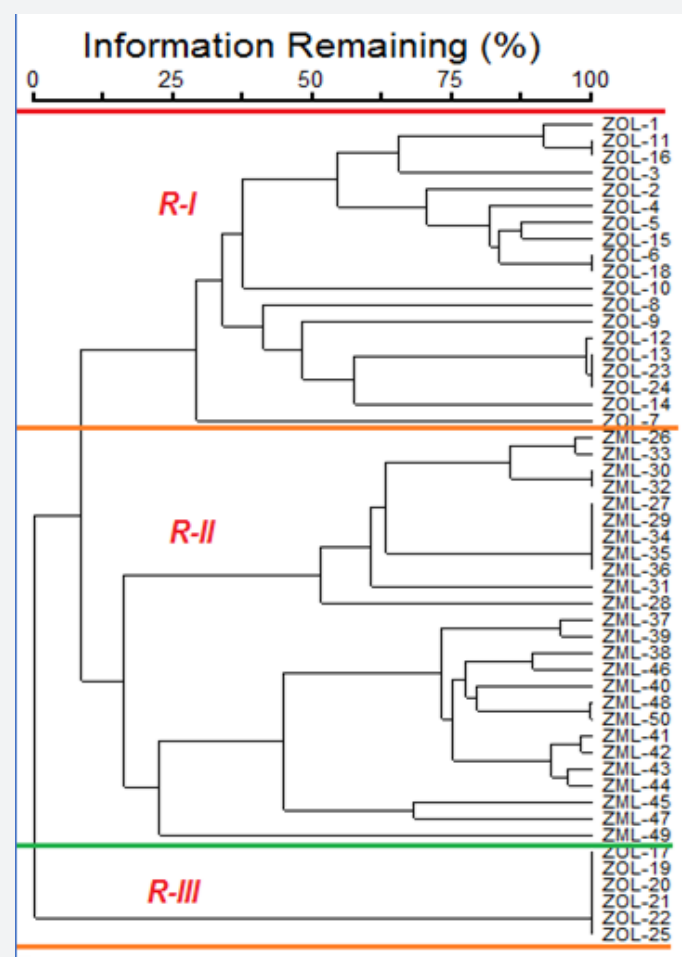

Figure 1: Inter -species phylogenetic relationship identified through morphological traits analysis in 50 different genotypes of Ziziphus species collected from Swat, KP, Pakistan ZOL indicate genotypes of Z. oxyphylla, and ZML represents Z. muritiana.

The double data matrix of 50 genotypes based on morphology was analyzed for the construction of phylogenetic tree to represents the similarity of various species or genera and the two species of the Ziziphus were investigated for similarities and the phylogenetic tree was constructed. The phylogenetic tree divided the two species in three groups R1. RII and RII (Figure 1). R1 and RII consisted of total genotypes of Z. oxyphylla. While the RII was into composed of all genotypes of $Z$. muritiana. The similarity indexes were performed for all the genotype of 2 species that was $23.529 \%$ for Z. muritiana and Z. oxyphylla (Table 5).

Table 5: Intra and interspecific genetic diversity in 17 morphological characters studied in Z. oxyphylla and Z. muritiana.

\begin{tabular}{|c|c|c|c|}
\hline Traits & Z. oxyphylla & Z. muritiana & $\begin{array}{c}\text { Trait Similarity } \\
\text { Index } \\
\text { Z.0 \& Z. M }\end{array}$ \\
\hline PH & 9.366 & 12.08 & NA \\
\hline BR & 8.5 & 9 & NA \\
\hline LL & 7.5 & 4.555 & NA \\
\hline LW & ${ }^{*} 5.0866$ & ${ }^{*} 5.952$ & ${ }^{*} 5.519$ \\
\hline LT & 5.8 & 4.065 & NA \\
\hline PL & ${ }^{*} 3.8889$ & ${ }^{*} 2.453$ & ${ }^{*} 3.171$ \\
\hline InL & 8.333 & 4.8 & NA \\
\hline StD & ${ }^{*} 3.9$ & ${ }^{*} 3.866$ & ${ }^{*} 3.883$ \\
\hline FtW & 24.5 & 16.4 & NA \\
\hline FtD & 5.8966 & 3.666 & NA \\
\hline FtL & 4.5666 & 3.06666 & NA \\
\hline LS & Ovate & Oblique & NA \\
\hline LC & ${ }^{*}$ Green & ${ }^{*}$ Green & ${ }^{*}$ Green \\
\hline LP & Absent & Present & NA \\
\hline FC & Purple White & White Blue & NA \\
\hline St & Rough/Smooth & Granular & NA \\
\hline SS & Flattened Shaped & Plano-convex & NA \\
\hline
\end{tabular}

Total TSI $=23.529 \%$ ((homologous trait/total traits $\left.){ }^{*} 100\right)$.

*- Traits similarity within two species.

\section{SDS- PAGE analysis}

Total 12 bands were observed in the both of species, the phylogenetic relationship among the 2 species through phylogenetic tree has been shown in the (Figure 2). The phylogenetic tree 
was divided into two regions. R-I comprised of only genotype of Z. oxyphylla collected from (KP, Pakistan), while Regon II consists

of genotypes of Z. muritiana collected from (KP, Pakistan) respectively.

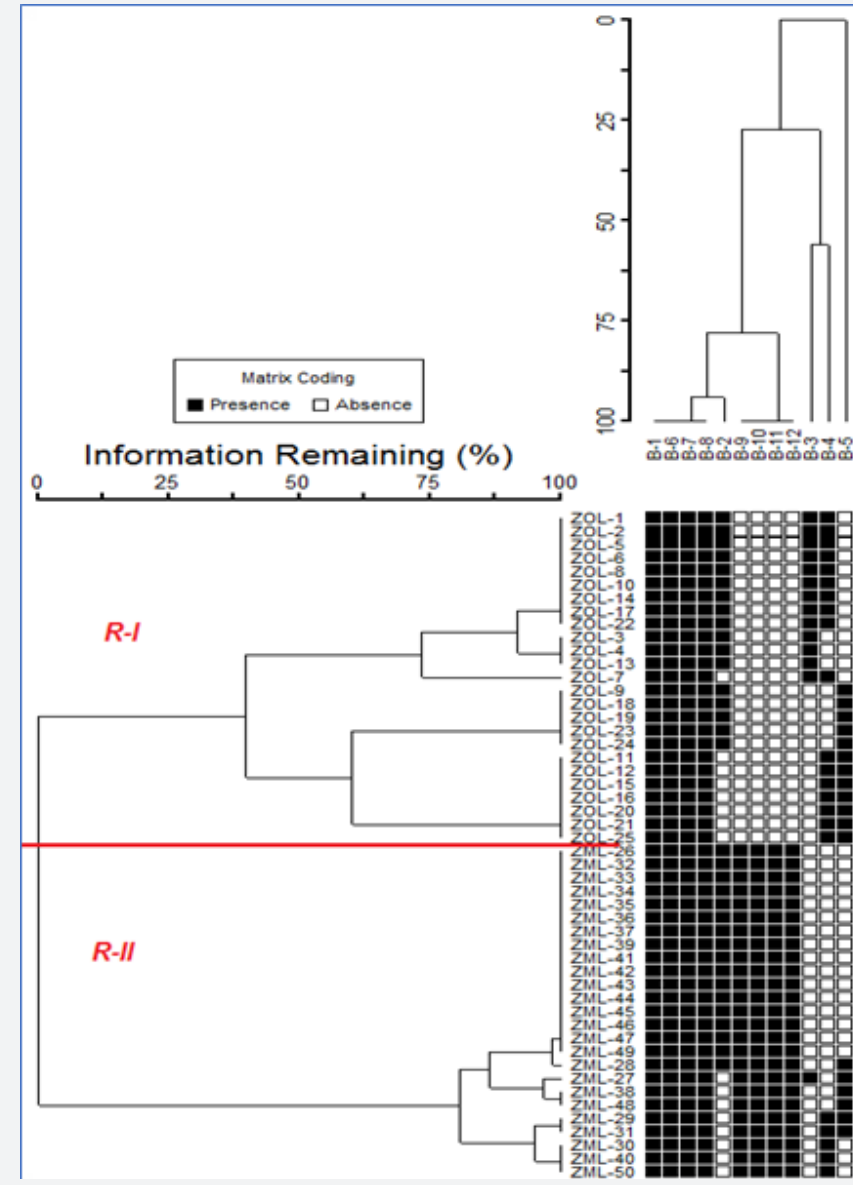

Figure 2: Intra and interspecific genetic diversity in 50 genotypes studied through SDS-PAGE in Z. oxyphylla and Z. muritiana.

\section{Locus variation}

Table 6 show interspecific variation among 50 genotypes of the Ziziphus (Z. oxyphylla and Z. muritiana) species. Among all the genotypes, 12 loci (L1-L12) were noted out of these L1, 6, 7 and 8 was monomorphic and were marked as generic specific which is used to discriminate the Ziziphus species. Moreover, the loci L-2, L-4, L-5, L-9, L-10, L-11 and L-12 marked as polymorphic with 34, $70,68,70,50,50,50$ and 50 percent genetic diversity, respectively. The inter species comparative locus contribution toward genetic disagreement (CLCTGD) was $66.66 \%$ in the two species of 50 Ziziphus genotypes (Table 6 and Figure 2). Intraspecific locus variation among 25 genotypes of $Z$. oxyphylla is represented in Table 7, Notably, L-9, 10, 11, 12 were absent in Z. oxyphylla. L-1, L-6, L-8 was monomorphic in Z. oxyphylla. While L-2, 3, 4 and L-5 was polymorphic and the locus contribution toward genetic disagreement (LCTGD) of Z. oxyphylla was $41.66 \%$ (Table 7).

The Table 7 represents the intraspecific variation among the 25 genotypes of $Z$. muritiana, exhibited high intra-specific locus variation. Among 12 loci, out of which $L-1,7,8,9,10,11$ and 12 was monomorphic, while L-2, L-4, L-5and L-6 were polymorphic.
The locus contribution toward genetic disagreement (LCTGD) of $Z$. muritaiana was 25\% (Table 7).

\section{Discussion}

Many of the local communities in the regions depends on the consumption of medicinal plants to use for the control/use against different number of diseases, However, the vanishing of these plant species is steadily reported chiefly due to fluctuations in the environment, land degradation and unsustainable use of these plants; moreover, the expansion of invasive species has donated a lot to their disappearance [41]. Conservation of medicinal plant genetic diversity has freshly created a lot of attention in the tropics as a result of many years of misconduct, adverse environment as well as socio-economic changes. Population genetic theory expects that the reduction in the genetic diversity limits a species ability to keep pace with the changing selection pressure [42]. Plant species mainly the medicinal plants rely on the existing genetic diversity for constancy and survival under the ever-fluctuating environments [43]. Understanding medicinal plants species population genetic structure is vital for their conservation, planning and justifiable organization [44]. 
Therefore, a common goal line of conservation is to preserve genetic diversity in "red listed" species, which is crucial for longterm survival and evolutionary response to the altering environment [45]. One main implication of this method, from the viewpoint of conservation genetics, is that it could help us set sampling intervals of areas within populations to optimize the genetic diversity in collections from local populations of rare, endangered, or endemic plant species [46]. For the purpose of conservation of plant species, most of the investigations deal only with determination of genetic diversity in individual populations [40].

The purpose of this study was to recognize the phylogenetic relationship, genetic diversity, genetic structure, and a core collection of Ziziphus species. Now, we explain our consequences with respect to genetic diversity and the causes of the genetic idleness. The current position of genetic structure is briefly debated. Moreover, we further clarify the competence of the plan used to build the core collection. Genetic redundancy is a significant issue in plant genetic resource management. The identification of duplicates is important in germplasm repositories, particularly when considering the construction of core collections [40].

Various apparatuses are now presented for documentation of required differences in the genotypes, including morphological / phenotypic, biochemical and molecular markers [40]. Though morphological description is the principal step in the description and alliance of crops genotypes, but these are highly subjective by the environment [40]. The double data matrix of 50 genotypes based on morphology was analyzed for the construction of phylogenetic tree to represents the similarity of various species or genera and the two species of the Ziziphus were investigated for similarities and the phylogenetic tree was constructed (Figure 1). The phylogenetic tree divided the two species in three groups R1, RII and RII (Figure 2). R1 and RII consisted of total genotypes of $Z$. oxyphylla. While the RII was into composed of all genotypes of $Z$. muritiana. The similarity indexes for all the genotype of 2 species was $23.529 \%$ for Z. muritiana and Z. oxyphylla [47].

The two plant species under the genus Ziziphus study exposed that no two plants have similar protein banding patterns which demonstrates the presence of genetic diversity between these species. The presence of common bands/locus (L-1, 6, 7, 8) among these two Ziziphus species suggests their close genetic similarity and common ancestry [40]. Also, [40] accredited the appearance of a common locus/band in all individual in a population to the fact that the gene coding for the enzyme or protein does not differ. Due to High inter-species locus contribution toward genetic disagreement SDS-PAGE could be a reliable technique for identification of these two species, while intra-specie locus contribution toward genetic diversity was high in genotypes of Ziziphus oxyphylla (41.66\%) as compare to Z. muritiana (25\%).

\section{Conclusion}

Best of our current study was first time to investigated that the seed protein and ethno medicinal uses of wild Ziziphus species collected from different regions of KP, Pakistan, the genetic pool of dissimilarity within genotypes and Z. oxyphylla and Z. mauritiana as well, is due to selection as well as for the crops/plants species improvement and their conservation for the better studies of genetic diversity and its distribution in the wild Ziziphus species of the studies needed duet to their conservation and will be help greatly to labeling what to conserve as well as where to conserve and will be and will enhance our information and understanding of the taxonomy, origin and evolution of wild Ziziphus species ( $Z$. oxyphylla and Z. mauritiana) respectively

\section{References}

1. De Omena MC, Navarro DMAF, De Paula JE, Luna JS, De Lima MF, et al. (2007) Larvicidal activities against Aedes aegypti of some Brazilian medicinal plants. Bioresour Technol 98(13): 2549-2556.

2. Al-Reza SM, Bajpai VK, Kang SC (2009) Antioxidant and antilisterial effect of seed essential oil and organic extracts from Zizyphus jujuba. Food Chem Toxicol 47(9): 2374-2380.

3. Adzu B, Amos S, Wambebe C, Gamaniel K (2001) Antinociceptive activity of Zizyphus spina-christi root bark extract. Fitoterapia 2(4): 344350 .

4. Nisar M, Adzu B, Inamullah K, Bashir A, Ihsan A, et al. (2007) Antinociceptive and antipyretic activities of the Zizyphus oxyphylla Edgew. leaves. Phytother Res 21(7): 693-695.

5. Perveen M Qaiser (2005) Pollen flora of pakistan-xliv. Rhamnaceae. Pak J Bot 37(2): 195-202.

6. Jan G, Khan MA, Gul F (2009) Ethnomedicinal plants used against jaundice in Dir Kohistan valleys (NWFP), Pakistan. Ethnobotanical leaflets 2009(8): 7.

7. Sher H (2011) Ethnoecological evaluation of some medicinal and aromatic plants of Kot Malakand Agency, Pakistan. Scientific Research and Essays 6(10): 2164-2173.

8. Khan MA, Khan SA, Qureshi MA, Ahmed G, Khan MA, et al. (2011) Ethnobotany of some useful plants of Poonch Valley Azad Kashmir. Journal of Medicinal Plants Research 5(26): 6140-6151.

9. Sher Z, Khan Z, Hussain F (2011) Ethnobotanical studies of some plants of Chagharzai valley, district Buner, Pak J Bot 43(3): 1445-1452.

10. Kaleem WA, Muhammad N, Khan H, Rauf A (2014) Pharmacological and phytochemical studies of genus Zizyphus. Middle-East J Sci Res 21(8): 1243-1263.

11. Jabeen A, Khan MA, Ahmad M, Zafar M, Ahmad F (2009) Indigenous uses of economically important flora of Margallah hills national park, Islamabad, Pakistan. African Journal of Biotechnology 8(5): 763-784.

12. Samreen U, Ibrar M, Naveed S, Khatak I (2016) Ethnobotanical study of subtropical hills of Darazinda, Takht-e-Suleman range FR DI Khan, Pakistan. Pure Appl Biol 5(1): 149-164.

13. Khan MA, Khan MA, Hussain M, Mujtaba G (2012) Medicinal plants used in folk recipes by the inhabitants of himalayan region Poonch Valley Azad Kashmir (Pakistan). J Basic Appl Sci 8: 35-45.

14. Zvaigzne G, Karklina D, Seglina D, Krasnova I (2009) Antioxidants in various citrus fruit juices. Chemine Technologija 3(52): 56-61.

15. Ozgen M, Scheerens JC, Reese RN, Miller RA (2010) Total phenolic, anthocyanin contents and antioxidant capacity of selected elderberry (Sambucus canadensis L.) accessions. Pharmacogn Mag 6(23): 198-208.

16. Waseem K, Ghaffoor A, Rehman SU (2002) Effect of fruit orientation on the quality of litchi (Litchi chinenesis Sonn) under the agro-climatic conditions of Dera Ismail Khan-Pakistan. Int J Agric Biol 4(4): 503-505. 
17. Kamiloglu O, Ercisli S, Sengül M, Toplu C, Serce S (2009) Total phenolics and antioxidant activity of jujube (Zizyphus jujube Mill.) genotypes selected from Turkey. Afr J Biotech 8(2): 303-307.

18. Razi MF, Anwar R, Basra SMA, Khan MM, Khan IA (2013) Morphological characterization of leaves and fruit of jujube (Ziziphus mauritiana Lamk.) germplasm in Faisalabad, Pakistan. Pak J Agric Sci 50(2): 211216.

19. Qamer S, Ehsan M, Nadeem S, Shakoori AR (2007) Free amino acids content of Pakistani unifloral honey produced by Apis mellifera. Pak J Zool 39(2): 99-102.

20. Gao QH, Wu PT, Liu JR, Wu CS, Parry JW, et al. (2011) Physico-chemical properties and antioxidant capacity of different jujube (Ziziphus jujuba Mill.) cultivars grown in loess plateau of China. Scientia Horticulturae 130(1): 67-72.

21. Collado-Gonzalez J, Cruz ZN, Rodriguez P, Galindo A, Diaz-Banos FG, et al. (2013) Effect of water deficit and domestic storage on the procyanidin profile, size, and aggregation process in pear-jujube (Ziziphus jujuba) fruits. J Agric Food Chem 61(26): 6187-6197.

22. Ecevit FM, San B, Dilmacunal T, Turk FH, Yildirim AN, et al. (2007) Selection of superior ber (Ziziphus jujuba L.) genotypes in civril region. J Agric 14(1): 51-56.

23. Batos B, Miljkovic D, Perovic M, Orlovic S (2017) Morphological variability of Quercus robur L. leaf in Serbia. Genetika 49(2): 529-541.

24. Hasanova S, Akparov Z, Mammadov A, Amirov L, Babayeva S, et al. (2017) Genetic diversity of chickpea genotypes as revealed by ISSR and RAPD markers. Genetika 49(2): 415-423.

25. Petrovic S, Maric S, Cupic T, Rebekic A, Rukavina I (2017) Assessment of molecular and phenotypic diversity among winter wheat cultivars. Genetika 49(2): 583-598.

26. Saroei E, Cheghamirza K, Zarei L (2017) Genetic diversity of characteristics in barley cultivars. Genetika 49(2): 495-510.

27. Yadegari M, Ansari MH (2017) Study of multivariate analysis of quantitative traits in Iranian pumpkin lines. Genetika 49(2): 425-433.

28. Jan SA, Shinwari ZK, Rabbani MA, Niaz IA, Shah SH (2017) Assessment of quantitative agro-morphological variations among Brassica rapa diverse populations. Pak J Bot 49(2): 561-567.

29. Izadpanah F, Kalantari S, Hassani ME, Naghavi MR, Shokrpour M (2015) Molecular and morphological variation in some Iranian saffron (Crocus sativus L.) accessions. Genetika 47(2): 711-722.

30. Arif M, Khurshid H, Uddin Siddiqui S, Jatoi SA, Ghafoor A (2017) Estimating Spatial Population structure through quantification of Oil content and phenotypic diversity in Pakistani Castor Bean (Ricinus communis L.) germplasm. Sci Technol Develop 34(3): 147-154.

31. Ghafoor A, Gulbaaz FN, Afzal M, Ashraf M, Arshad M (2003) Inter-relationship between SDS-PAGE markers and agronomic traits in chickpea (Cicer arietinum L.). Pak J Bot 35(4): 613-624.

32. Haliem EA, Al-Huqail AA (2013) Comparative sodium dodecyl sulfate-polyacrylamide gel electrophoresis and restricted fragment length polymorphism among fenugreek accessions. Genet Mol Res 12(4): 6284-6298.
33. Dhawale RN, Mahalle MD, Paul NS (2015) Biochemical marker (Protein) based characterization of rice accessions bio-diversity in international rice molecular breeding programme. Asian J Biomedical and Pharma Sci 5(43): 31-37.

34. Javaid A, Ghafoor A, Anwar R (2004) Seed storage protein electrophoresis in groundnut for evaluating genetic diversity. Pak J Bot 36(1): 25 29.

35. Iqbal SH, Ghafoor A, Ayub N (2005) Relationship between SDS-PAGE markers and Ascochyta blight in chickpea. Pak J Bot 37(1): 87-96.

36. Martin JF, Birkenholz RJ (1995) Rural and Urban Adult Knowledge and Perceptions of Agriculture. Journal of Agricultural Education 36(2): 4453.

37. Alexiades MN, Sheldon JW (1996) Selected Guidelines for Ethnobotanical Research: A Field Manual. The New York Botanical Garden, New York, pp. 306.

38. Trotter RT, Logan MH (1986) Informant census: A new approach for identifying potentially effective medicinal plants. In: Etkin LN (Ed.), Plants in indigenous medicine and diet. Redgrave, Bedford Hill, New York, pp. 91-112.

39. Muhammad N, Wadood SF, Khan W, Ali N, Nisar M (2018b) Intra-species profiling of Cleome viscosa growing in Swat district (Pakistan). Biosystem Diversity 26-52.

40. Muhammad N, Ali N, Nisar M, Abd Allah EF, Hashem A, et al. (2018a) Genetic Diversity Within Natural Populations of the Medicinal Plant Rhynchosia minima (L.) Dc. Applied Ecology and Environmental Research 16(5): 5633-5651.

41. Mohammed A, Kidanu A, Mohamed A, Asrat P, Abera K, et al. (2011) Dire Dawa Administration Program of Adaptation to Climate Change. DDAEPA. Dire Dawa, Ethiopia. pp. 133.

42. Young AG, Merriam HG, Warwick SI (1993) The effect of forest fragmentation on genetic variation in an Acer saccharium. (March sugar maple) population. Heredity 71: 277-289.

43. National Research Council (1991) Animals as sentinels of environmental health hazards. Washington: National Academies Press, USA, pp. 176.

44. Sun B, Conceicao L, Ricardo D, Silva JM, Spranger I (1998) Separation of grape and wine proanthocyanidins according to their degree of polymerization. Journal of Agricultural and Food Chemistry 46(4): 13901396.

45. Hueneke FL (1991) Ecological implication of genetic variation in the plant populations. In: Falk DA \& Holsinger KE (Eds.), Genetic diversity and conservation of the rare plants. Oxfords university press, New York, USA, pp. 31-44.

46. Chung KT, Wong TY, Huang YW, Lin Y (1998) Tannins and human health: a review. Crit Rev Food Sci Nutr 38(6): 421-464.

47. Sharma GN, Gaur A (2013) Ziziphus mauritiana Lamk-an overview. Indo American J Pharmaceutical Res 3(6): 4560-4566. 
Your next submission with Juniper Publishers will reach you the below assets

- Quality Editorial service

- Swift Peer Review

- Reprints availability

- E-prints Service

- Manuscript Podcast for convenient understanding

- Global attainment for your research

- Manuscript accessibility in different formats ( Pdf, E-pub, Full Text, Audio)

- Unceasing customer service

Track the below URL for one-step submission https://juniperpublishers.com/online-submission.php 